\title{
Unusual dual genital duct remnants in true hermaphroditism
}

\author{
C WILliAMS* AND I A HUGHES
}

From the Departments of Pathology and Child Health, University of Wales College of Medicine, Heath Park, Cardiff CF4 $4 X N$.

SUMMARY A case of true hermaphroditism is reported in which a $46, \mathrm{XY}$ karyotype was associated with a testis and an ovotestis. The dual presence of a Fallopian tube and a vas deferens on the side of the ovotestis is documented as a previously unreported finding.

In true hermaphroditism both ovarian and testicular tissue are present in the same subject. The nature of the genital ducts adjacent to the gonads is of particular interest; it is generally accepted to be related to the ability of testicular tissue to stimulate the development of the Wolffian ducts and induce regression of the Müllerian ducts. ${ }^{1}$ A case of true hermaphroditism in which both vas deferens and Fallopian tube were present on the same side as an ovotestis is described.

\section{Case report}

The proband was the first child of healthy, unrelated parents. The pregnancy was uneventful and spon-

* Present address: Department of Pathology, Memorial Hospital, Darlington DL3 6HX.

Received for publication 21 ()ctober 19x6.

Revised version accepted for publication is February 1987 taneous delivery occurred at term. Birth weight was $3.05 \mathrm{~kg}$. There was no relevant family history.

Ambiguous genitalia were noted at birth. There $\overrightarrow{\vec{\omega}}$ was an enlarged clitoris surrounded by fused rugose labial folds. No gonads were palpable. There was a single perineal urethral opening. The remainder of the examination was normal.

The peripheral karyotype determined on two $\omega$ separate occasions was $46, X Y$ with no evidence of N mosaicism. A total of 78 mitoses was counted and no abnormality was detected using $\mathrm{G}, \mathrm{C}$, and $\mathrm{Q} \stackrel{\circ}{?}$ banding techniques. The plasma $170 \mathrm{H}$ progesterone $\overrightarrow{\vec{z}}$ concentration was normal $(8 \mathrm{nmol} / \mathrm{l})$ thus excluding 21-hydroxylase deficiency. ${ }^{2}$ Plasma testosterone $\frac{\not}{3}$ concentrations increased from $3 \cdot 1$ to $6.7 \mathrm{nmol} / 1$ after three daily injections of human chorionic gonado- $\odot$ trophin (HCG $2000 \mathrm{IU} /$ day). A perineal sinogram $@$ showed a left cornuate uterus and Fallopian tube. An intravenous pyelogram was normal. Laparotomy performed at the age of 11 months by Mr J Lari showed a normal sized uterus for age to which a left Fallopian tube was attached. Both gonads were $\frac{D}{D}$ found in the ovarian position. The gonads and adnexal ducts were excised and the uterus left in $\frac{0}{3}$ place. A reduction clitoroplasty was also performed.

The left gonad was an irregular white nodule measuring $1.5 \times 1.0 \times 0.3 \mathrm{~cm}$ to which a $1 \mathrm{~cm}$ length

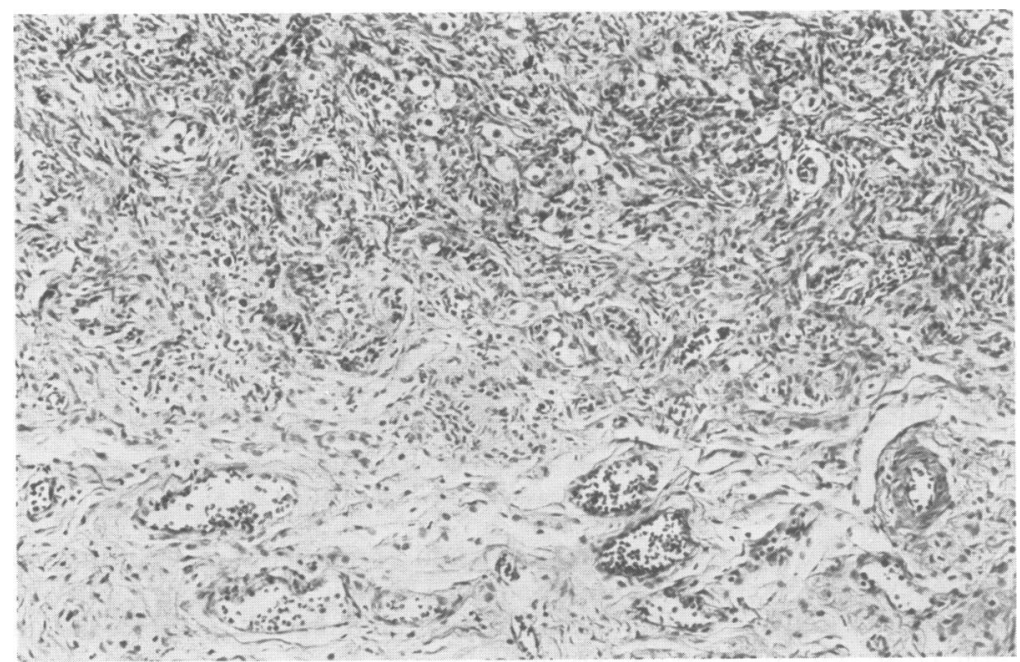

FIG 1 Ovotestis. Ovarian stroma containing a number of primordial follicles. 
of cylindrical tissue $0.3 \mathrm{~cm}$ in diameter was attached. Histologically the bulk of the gonad consisted of ovarian tissue containing primordial follicles (fig 1). A small amount of testicular tissue in the form of tubules lined by Sertoli cells was present at one margin (fig 2). The line of demarcation between ovary and testicular tubules was abrupt. The tissues around the gonad showed both normal Fallopian tube and normal epididymis and vas deferens (fig 3 ). The ductal structures were separated by a short amount of loose connective tissue. The more distal regions of the adnexal duct showed only a Fallopian tube.
The right gonad had the appearance of a small immature testis. The seminiferous tubules were lined by immature Sertoli cells and contained small numbers of germ cells. The associated ducts were an epididymis and vas. Karyotype analysis of the testis based on five mitotic counts was $46, \mathrm{XY}$.

\section{Discussion}

The classification of true hermaphroditism is based upon the lateral distribution of gonadal tissue. While an ovotestis is the most common gonad in true hermaphroditism, the combination of an
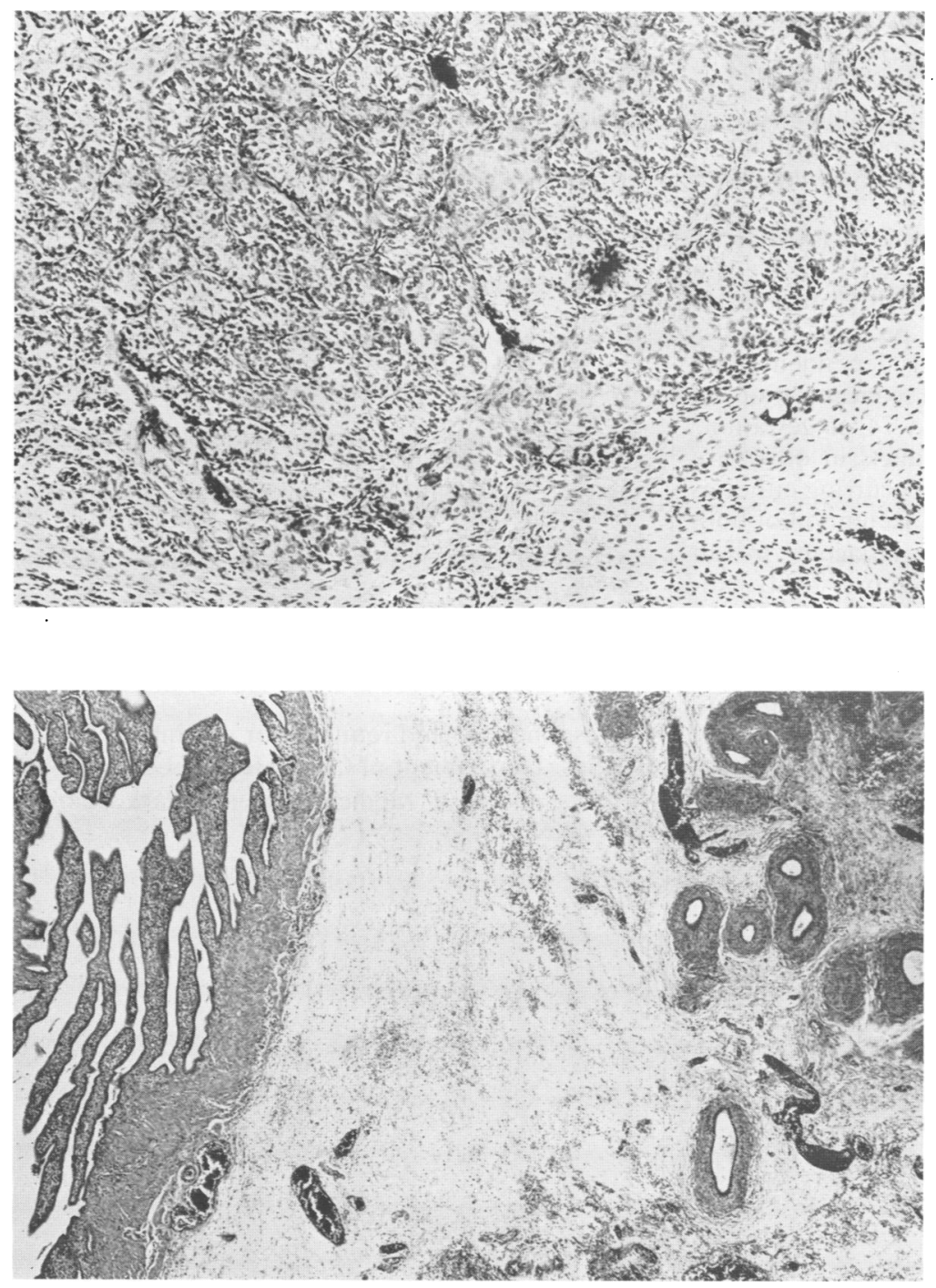

FIG 2 Ovotestis. Seminiferous tubules lined by Sertoli cells.

FIG 3 Gonadal ducts. Dual presence of a Fallopian tube (left) and epididymis and vas deferens (right). 
ovotestis with a testis is rare and occurs in only $10 \%$ of cases. A 46, XY karyotype is also uncommon, present in $11.6 \%$ of all cases. This case fulfils the criteria of true hermaphroditism because of the presence of a testis on the right and an ovotestis containing primordial follicles on the left side. The condition must be differentiated from mixed gonadal dysgenesis. ${ }^{3}$ This is characterised by a unilateral testis, a streak gonad (lacking follicles or testicular tubules) on the contralateral side, and persistent Müllerian structures, frequently in the form of a uterus and bilateral Fallopian tubes. The karyotype usually shows $\mathrm{XO} / \mathrm{XY}$ mosaicism.

The nature of the genital duct associated with an ovotestis is a matter of considerable interest. In the series of 48 patients reviewed by van Niekerk, ${ }^{4}$ either a Fallopian tube was present (in $65 \%$ ) or there was a vas deferens (in $35 \%$ of cases). The normal development of the internal genital ducts is determined by the presence or absence of adjacent testicular tissue. ${ }^{1}$ Müllerian duct regression in males is mediated between day 62 and 77 of human gestation by anti-Müllerian hormone (AMH), a protein derived from fetal Sertoli cells. ${ }^{5}$ There is a period of maximum sensitivity to AMH during this early phase of gestation. The process precedes Wolffian duct stabilisation which is dependent upon the production of a high local concentration of testosterone between day 71 and 74 of gestation.

The persistence of Müllerian ducts in otherwise normal males is well recognised, occurring either as a sporadic or familial disorder. ${ }^{67}$ Retention of both Müllerian and Wolffian ducts adjacent to an ovotestis has not been described previously. Inappropriate timing of adequate $\mathrm{AMH}$ release coupled with insufficient Leydig cell synthesis of testosterone is one possible reason for this unique observation, but the hypothesis is impossible to prove postnatally. Perhaps the indifferent gonad failed to grow to a critical size before differentiation into a testis. ${ }^{8}$ It has been proposed by Cunha et a $l^{\prime}$ that complex hormonal effects involving epithelial morphogenesis result from cell-cell communication $\stackrel{\overparen{D}}{=}$ between mesenchyme and epithelium. An alterna- $\overrightarrow{\vec{S}}$ tive hypothesis is that cells (perhaps mesenchymal) responsible for Müllerian duct regression did not establish appropriate mesenchymal/epithelium re- $\frac{}{\omega}$ lationships at the critical time.

The gonads and internal genital ducts in all cases of true hermaphroditism should be examined carefully to document whether the coexistence of $\overrightarrow{0}$ Müllerian and Wolffian duct remnants adjacent to the same gonad occurs more often than previously $\vec{\omega}$ recognised.

We thank Mr S Roberts and Miss E Little for the i cytogenetic studies and Dr R Prosser for referring the patient.

\section{References}

I Jost A, Vigier B, Prepin J, Perchellet JP. Studies on sexual differentiation in mammals. Recent Prog Horm Res 1973;29: $<$ 1-35.

2 Hughes IA, Riad-Fahmy D, Griffiths K. Plasma $170 \mathrm{H}-\stackrel{\bar{\Upsilon}}{\supset}$ progesterone concentrations in newborn infants. Arch Dis Child 1979;54:347-9.

3 Davidoff F, Federman DD. Mixed gonadal dysgenesis. Pediatrics 1973;52:725-40.

4 van Niekerk WA. Truc hermaphroditism. In: Josso N, ed. The intersex child. Basel: Karger, 1981:80-9.

5 Donahue DK, Budzik GP, Trelstad R, et al. Müllerian inhibiting substance: an updatc. Recent Prog Horm Res 1982;38: 279-326.

- Sloan WR, Walsh PC. Familial persistent Müllerian duct $\stackrel{\circ}{\overparen{D}}$ syndrome. J Urol 1976;115:459-61.

7 Brook CGD, Wagner H, Zachmann M, et al. Familial occur- $\overline{\bar{O}}$ rence of persistent Müllerian structures in otherwise normal 3 males. Br Med J 1973;i:771-3.

$\therefore$ Mittwoch U. Males, females and hermaphrodites. Ann Hum Genet 1986;50:103-21.

- Cunha GR, Taguclin O, Shannon JM, et al. Mesenchymal role in hormone-induced epithelial development. In: Serio M, Motta M, Zanisi M, Martini L, eds. Sexual differentiation: basic and $\overline{0}$ clinical aspects. New York: Raven Press, 1984:33-51.

Correspondence and requests for reprints to Dr I A Hughes, Department of Child Health, University of

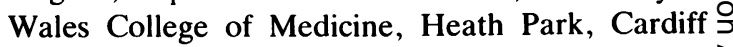
CF4 4XN. 